\title{
Implementation of Hospital Occupational Health and Safety Regulations to Minimize Occupational Accidents at the Sultan Agung Islamic Hospital, Semarang
}

\author{
Radit H. Mayangkara'), Achmad Arman Subiyanto'), Didik Gunawan Tamtomo²) \\ ${ }^{1)}$ Masters Program in Public Health, Universitas Sebelas Maret \\ 2)Faculty of Medicine, Universitas Sebelas Maret
}

\section{ABSTRACT}

Background: Sultan Agung Islamic Hospital Semarang, which is one of the providers in the health sector, has complex and continuous activities which in turn have the potential to cause various impacts and risks, such as work accidents, nosocomial infections, and occupational diseases. Therefore, more detailed observations are needed on the enforcement of occupational health and safety regulations to minimize these impacts. This study aims to determine the application of occupational health and safety hospital regulations to minimize work accidents at Sultan Agung Hospital, Semarang.

Subjects and Method: This study was conducted using a qualitative approach. The key informants in this study were the Director of the Sultan Agung Islamic Hospital totaling 1 person and the supporting informants were the field staff of the Sultan Agung Hospital totaling 17 people. Data collection techniques were carried out by direct observation, question- naires and focus group discussions. The data analysis technique used in this study is Narrative Analysis.

Results: This study was conducted using a qualitative approach with data collection techniques by direct observation, questionnaires and focus group discussions.

Conclusion: Regulations are still drawn up sectorally by various agencies that regulate occupational health and safety in hospital so that efforts to minimize the number of work accidents are quite difficult.

Keywords: occupational health and safety, Sultan Agung Islamic Hospital, work accidents

\section{Correspondence:}

Radit Hartantyo Mayangkara. Masters Program in Public Health, Universitas Sebelas Maret. Jl. Ir. Sutami 36A, Surakarta 57126, Central Java. Email: raditmayangkara@gmail.com. Mobile: $(+62) 8122938885$.

\section{Cite this as:}

Mayangkara RH, Subiyanto AA, Tamtomo DG (2021). Implementation of Hospital Occupational Health and Safety Regulations to Minimize Occupational Accidents at the Sultan Agung Islamic Hospital, Semarang. J Health Policy Manage. 06(03): 160-167. https://doi.org/10.26911/thejhpm.2021.06.03.01.

c) (i) Journal of Health Policy and Management is licensed under a Creative Commons Attribution-NonCommercial-ShareAlike 4.0 International License.

\section{BACKGROUND}

The potential hazard due to work accidents in health facilities is very large. When compared with the general workforce, workers in health facilities are more likely to suffer from sprains and injuries, infections, dermatitis, hepatitis, mental disorders, eye diseases, influenza, and others (Asih, 2018). The development of hospitals as referral health care facilities in Indonesia has been very rapid lately, both in terms of number and utilization of medical technology. Hospitals as health care facilities must prioritize improving the quality of services to the community without ignoring the efforts of Occupational Safety and Health (K3) for all hospital workers (ILO-WHO, 2005).

Increased utilization of health service facilities by the community must be follow- 
ed by demands for maximum management of the Occupational Health and Safety program in hospital (K3RS) because Hospital Human Resources (HR), visitors/ patients, patients and the community around the Hospital want to get protection from health problems and work accidents, even though the conditions of the facilities and infrastructure in the hospital do not meet the standards (Nasri, 2002).

The hospital is a unique and complex workplace to provide health services for the community (Kim and Jung, 2016). The wider the health services and functions of the hospital, the more complex the equipment and facilities needed. This complexity causes a huge potential danger, not only for patients and medical personnel, but also hospital visitors (Dahal, 2017). Potential hazards in hospitals, apart from infectious diseases, there are also other potential hazards that affect the situation and conditions in hospitals, namely accidents (explosion, fire, accidents related to electrical installations, and other sources of injury), radiation, hazardous chemicals, anesthetic gases, psychosocial and ergonomic disorders (Asih, 2018). Based on data and facts that occur today in America 5,000 health workers are infected with Hepatitis B, 47 are HIV positive (per year), and every year 600,000 - 1,000,000 needle stick injuries are reported (estimated more than 60\% are not reported). Hospital female staff who were exposed to anesthetic gases, significantly increased spontaneous abortion, children born with congenital abnormalities (National Institute for Occupational Safety and Health. 2010). In Indonesia, subjective complaints of low back pain based on data taken from hospitals in Jakarta in 2006 were known to be $83.3 \%$ of workers, most patients were aged 30-49: 63.3\% (Kementerian Kesehatan Republik Indonesia, 2010).
The government as a regulator of the implementation of occupational health and safety has issued many regulations such as Minister of Health Regulation No. 66 of 2016 concerning Hospital Occupational Safety and Health, Decree of the Minister of Health of the Republic of Indonesia No. 1087/Menkes/SK/VIII/2010 concerning Occupational Health and Safety Standards in Hospitals, and several other regulations and standard operating procedures.

Hazard handling can be followed up with the application of $\mathrm{K}_{3}$ regulations. The $\mathrm{K} 3$ regulation concerns several aspects such as training, identification of hazard sources, observation of $\mathrm{B}_{3}$ materials (Hazardous and Toxic Materials), and incident handling. One of the health facilities in the city of Semarang is RSI Sultan Agung. In the process of implementing this $\mathrm{K}_{3}$ regulation, the hospital is still not running optimally.

Sultan Agung Islamic Hospital is a private hospital in Semarang which is managed by the Sultan Agung Waqf Foundation. RSI Sultan Agung Semarang, which is a provider in the health sector, has complex and continuous activities. This complex and continuous activity creates many impacts and risks that may arise, such as work accidents, nosocomial infections, and occupational diseases. Therefore, more detailed observations are needed on the enforcement of $\mathrm{K}_{3}$ regulations to minimize these impacts.

Based on the problems mentioned above, this research has been carried out with the aim of knowing the extent to which the application of $\mathrm{K}_{3} \mathrm{RS}$ regulations to minimize work accidents at Sultan Agung Hospital, Semarang.

\section{SUBJECTS AND METHOD}

\section{Study Design}

This study was conducted at the Sultan Agung Hospital, Semarang. This study data 
collection was carried out in September to October 2019. This study was conducted using a qualitative approach which is a type of research whose findings are not required through statistical procedures. Qualitative study methods are also known as naturalistic research, which is a research conducted in natural conditions (natural setting).

\section{Informants}

Respondents/informants in this study were the President Director of the Sultan Agung Islamic Hospital, Semarang as the party who knew about the policy and implementation of the $\mathrm{K}_{3}$ regulations set at the Sultan Agung Islamic Hospital, Semarang, and the leaders of the Sultan Agung Islamic Hospital, the second Head of the $\mathrm{K}_{3}$ subdivision as the have information as managers and implementers in the field who know better about the situation and conditions and developments in the implementation of $\mathrm{K}_{3}$ enforcement. The third doctor is the party who interacts directly with the patient in the first treatment. Fourth, Nurses are the parties who manage patient management at any time on an ongoing basis. The five field sanitation employees as subjects who are seen as health quality and as individuals who are directly bound by $\mathrm{K}_{3}$ regulations at Sultan Agung Islamic Hospital, Semarang.

\section{Data Collection Technique}

The data collection techniques used were direct observation, questionnaires, and Focus Group Discussion (FGD).

\section{Data Validity}

The data validity technique is done by using a triangulation approach.

\section{Data Analysis}

The data analysis of this research was carried out with a narrative analysis approach.

\section{RESULTS}

From the results of direct observations of researchers at the location of the Sultan Agung Islamic Hospital, there are a number of safety signs for hospital workers and visitors. This is in line with the Regulation of the Minister of Health of the Republic of Indonesia Number 52 of 2018 concerning Occupational Safety and Health in Health Service Facilities.

Characteristics of respondents to the questionnaire Director of the Hospital who has an education level of $\mathrm{S} 1$ in the medical profession and S2 in Master of Health, the Manager of Medical Services with a background in the study of $\mathrm{S}_{1}$ in the Medical Profession, and 5 field employee respondents with a study background of S1 in Public Health and S1 in the Nursing Profession, in this case they are in accordance with the criteria Occupational Health and Safety on Human Resources K3RS Standard for Class B General Hospital in the Decree of the Minister of Health of the Republic of Indonesia No. 1087/Menkes/ SK/VIII/2010 concerning Occupational Health and Safety Standards in Hospitals.

The results of observations through questionnaires showed that most of the respondents understood quite clearly about the existence of the $\mathrm{K}_{3} \mathrm{RS}$ program. The $\mathrm{K}_{3}$ program has also been carried out periodically. The availability of $\mathrm{K}_{3}$ teaching aids in the hospital environment has also fulfilled several regulatory demands.

The results of the focus group discussion show that $\mathrm{K}_{3} \mathrm{RS}$ regulations are already available but are still being drawn up on a sectoral basis by authorized institutions. There are still many obstacles in reporting $\mathrm{K}_{3}$ incidents because the instruments in the regulation are sometimes very contradictory to each other. 


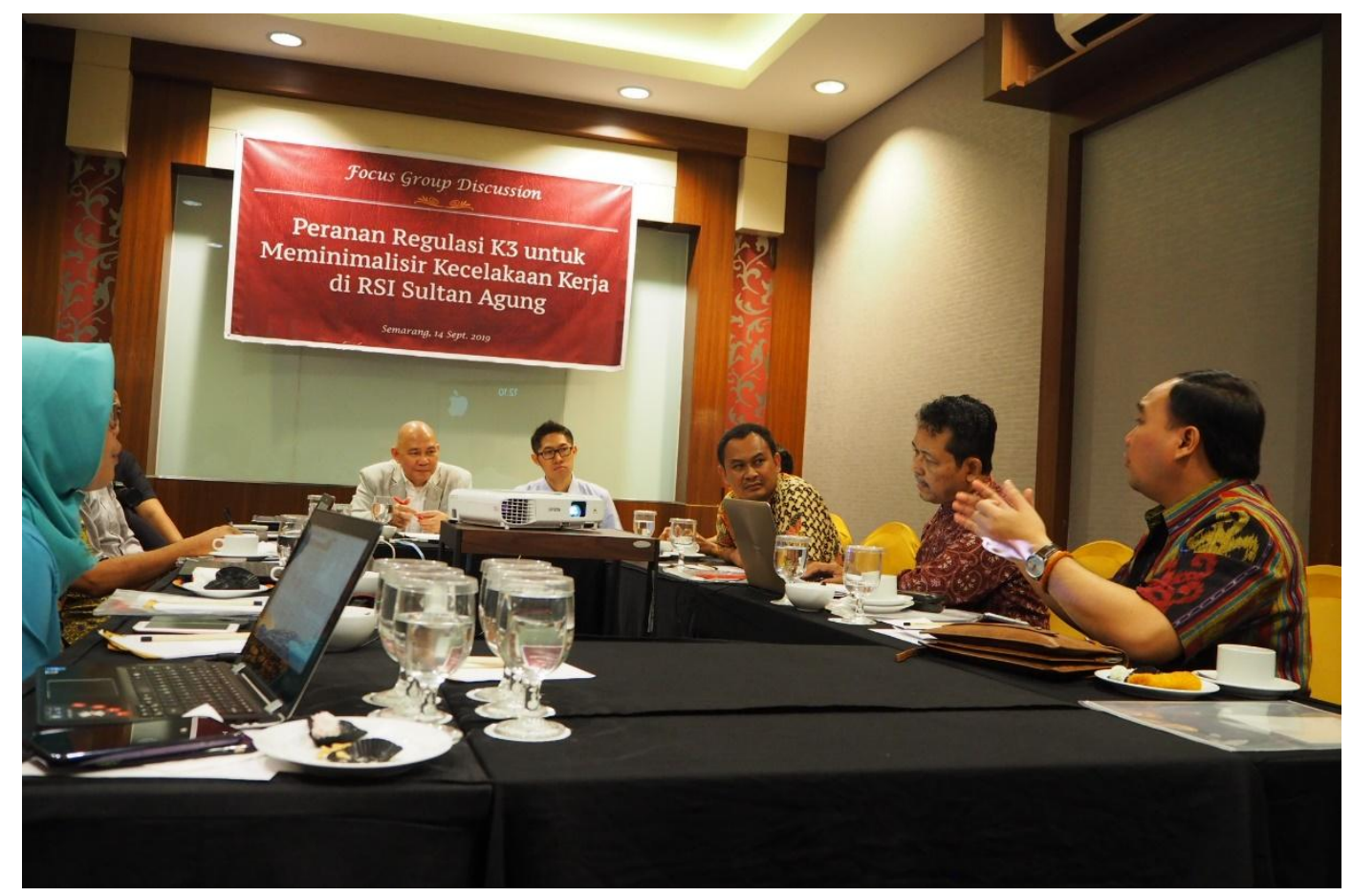

\section{Figure 1. Implementation of the Focus group discussion on the implementation of hospital occupational health and safety}

\section{DISCUSSION}

Sultan Agung Islamic Hospital has shown a commitment to protecting workers from possible work accidents. From the results of the study, it can be seen that the hospital management has made maximum efforts to introduce the hospital Occupational Health and Safety Regulations ( $\mathrm{K}_{3} \mathrm{RS}$ ) program to all existing workers. It can be seen that most of the respondents are aware of the $\mathrm{K}_{3} \mathrm{RS}$ program including the existence of the $\mathrm{K}_{3}$ Commission, regular review of the $\mathrm{K}_{3}$ program, socialization of the $\mathrm{K}_{3}$ program, and the provision of teaching aids about $\mathrm{K}_{3}$ in the hospital environment.

The formation of the OHS structure and organization has also been realized although the composition of its membership still has to be improved according to existing regulations, such as Permenkes 66/2016 concerning Hospital Occupational Safety and Health and Decree of the Ministry of Health of the Republic of Indonesia
No. 1087/MENKES/SK/VIII/2010 concerning Occupational Health and Safety Standards in Hospitals. It is realized that the fulfillment of human resources in accordance with existing regulations is a major problem in almost all hospitals in Indonesia. Human resources placed in the $\mathrm{K}_{3} \mathrm{RS}$ committee are still often just a formality, not yet touching on the competencies required by regulations. HR competencies that are in accordance with the required standards are a common problem in most hospitals in Indonesia considering that special education on occupational safety and accidents is still minimally available. However, this obstacle is not an excuse for not paying attention to safety risks and work accidents that may occur to all workers and even patients and visitors at the hospital.

From the results of observations on the Hospital Occupational Health and Safety Management System (SMK 3) in accord- 
ance with Permenkes 66/2016 paragraph 3, RSI Sultan Agung has consistently carried out these rules.

Sultan Agung Islamic Hospital has attempted to carry out various programs in relation to planning, implementing, monitoring and evaluating performance, and reviewing and improving the performance of effective $\mathrm{K}_{3} \mathrm{RS}$ to achieve the successful implementation of Hospital SMK3.

The obedience of Sultan Agung Islamic Hospital to Minister of Health Regulation 66/2016, especially in implementing hospital occupational safety and health standards, seems to be quite good, because it seeks to carry out several programs related to $\mathrm{K}_{3} \mathrm{RS}$ risk management; Hospital safety and security; Occupational Health Services; Management Hazardous and Toxic Materials (B3) from occupational safety and health aspects; Fire prevention and control; Hospital infrastructure management from occupational safety and health aspects; Medical equipment management from occupational safety and health aspects; and Preparedness for emergency or disaster conditions.

In accordance with the results of the study, it can be seen that the Sultan Agung Islamic Hospital has made improvements to the quality of human resources through general $\mathrm{K}_{3} \mathrm{RS}$ training for the Hospital ranks. In addition, there has also been delivery of hospital human resources to attend training/seminars/workshops on $\mathrm{K}_{3}$ in official institutions. However, some personnel in the OSH committee of the Sultan Agung Islamic Hospital have not received or have not received their turn to take part in additional education and training in accordance with the $\mathrm{K}_{3} \mathrm{RS}$ program.

The recording and reporting system has been implemented by the Sultan Agung Islamic Hospital. In addition, a system (flow) of incident reporting (near miss and accident) and follow-up has been made, as well as documentation of incident reporting (near injury and misfortune). However, there are several obstacles faced by workers who experience incidents in the workplace. Incidents in question can be in the form of: incidents of communicable diseases, incidents of non-communicable diseases, incidents of work-related accidents, and incidents of occupational diseases.

The obstacle that often occurs for valid recording and reporting is the reluctance of workers who have work accidents to report their incidents to the management of Sultan Agung Islamic Hospital. Some of the reasons employees do not report are as follows: 1). Workers affected by work accidents are lazy to report because reporting procedures are considered complicated and lengthy. 2). To get a claim, workers are faced with a long bureaucracy so that it takes a lot of time and also has an impact on costs that are also bigger. As a result, there is an imbalance between the costs incurred for treatment and the claims obtained. From these constraints, there are often relatively high incidence rates but low reporting rates.

Health services for workers who experience work accidents are an obstacle because of regulations that do not support inter-agency. In Permenkes 66/2016 article 27 paragraph 1 requires: To support the implementation of $\mathrm{K}_{3} \mathrm{RS}$, the Hospital can form a separate Occupational Health service unit or be integrated with the outpatient service unit in the Hospital, which is intended for Hospital HR. Meanwhile, under current conditions, in the BPJS era, sick people will not seek treatment at their own hospital, but must go through a Health Service Provider (PPK).

In the field of Assessment, the implementation of $\mathrm{K}_{3} \mathrm{RS}$ encountered many obstacles because of the many agencies 
involved in this process. Hospitals are basically under the control of the Ministry of Health, but the workers in them are under the auspices of the Ministry of Manpower. On the other hand, hospitals must also follow the assessment standards of various agencies, whether it is from the Hospital Accreditation Committee (KARS), maybe also from the Ministry of Health, the Ministry of Manpower, and maybe also from the Ministry of Education and Culture (considering there are connection with the Faculty of Medicine). OHS assessment or reporting documents in accordance with Permenkes 66/2016 are often not used by the Hospital Accreditation Committee. Many of the assessment standards (which are listed in Permenkes 66/2016) are not related to the standards of assessment by KARS.

Regarding the field of guidance and supervision of the implementation of $\mathrm{K}_{3} \mathrm{RS}$, the existing regulations are still felt to be less supportive. The supervision which according to Permenkes 66/2016 is carried out by the Minister, Head of Provincial Health Office, and Head of District/City Health Office, in accordance with their respective authorities feels not very effective, moreover the existing sanctions according to Permenkes 66/2016 are only administrative sanctions that will not provide a deterrent effect on negligence in the implementation of $\mathrm{K}_{3} \mathrm{RS}$.

So far, supervision has only revolved around visitations that do not touch $\mathrm{K}_{3}$. For example, the City Health Office is more focused on visiting the values of quality and safety standards (solid and liquid waste management, sanitation management, fulfillment of water source quality, hospital environmental quality standards, and the like).

Based on the research that has been done, it is known that Sultan Agung Islamic
Hospital has tried to fulfill various regulatory demands related to K3RS. Sultan Agung Islamic Hospital's commitment to K3RS was realized by issuing the Regulation of the Director of the Sultan Agung Islamic Hospital Number: 12,592/PER/RSI-SA/V/2019 concerning the Organizational Guidelines for the Occupational Health and Safety Committee of the Sultan Agung Islamic Hospital.

This commitment is faced with various obstacles due to the fact that various regulations have been found. The regulations are still made sectorally (sporadic) in the sense that subjects and objects that should be coordinated are not carried out. Hospital $\mathrm{K}_{3}$ is not only under the health sector, but also manpower, environment, and education, all of which have their own rules.

$\mathrm{K}_{3}$ includes public services. In public services, there are 4 instruments that regulate it, namely juridical/legal instruments, institutional instruments, financial instruments, and human resources instruments. In legal instruments, there must be legal certainty considering the basic values of the law include certainty, justice, and expediency. In practice, the main thing is legal certainty. In legal certainty, what is wrong must still be processed. The implementation must be in accordance with what is written in the law/regulation. Because the Minister of Health Regulation 66/2016 states that $\mathrm{K}_{3} \mathrm{RS}$ is mandatory, then as a consequence those who do not implement it must be given sanctions. Given that the sanctions in accordance with the regulation are only administrative, the deterrent effect will not appear for violators of the law. Laws that have aspects of repression and prevention must really be carried out consistently. Success in implementing regulations actually also depends on intentions. Intentions in accordance with the reasons 
for the formation of regulations really must be considered. If the implementation of regulation is according to intention, then the result will be good, but if the application of regulation is only based on formality, the result will be different. For example, if in a hospital the application is only to pursue accreditation, then the results may not be optimal. Accidents and worker safety are just decorations, not an intention to minimize incidents.

\section{AUTHOR CONTRIBUTION}

Researcher as the main researcher.

\section{FUNDING AND SPONSORSHIP}

This study is self-funded.

\section{CONFLICT OF INTEREST}

There is no conflict of interest in this study.

\section{REFERENCE}

Al-Khatib IA, El Ansari W, Areqat TA, et al (2015). Occupational safety precautions among nurses at four hospitals, Nablus district, Palestine. Int J Occup Environ Med. 6(4): 243-246. https://doi.org/10.15171/ijoem.2015.581.

Alingh CW, van Wijngaarden JDH, Huijsman R, Paauwe J (2018). The influence of environmental conditions on safety management in hospitals: a qualitative study. BMC Health Services Research. 18(1): 313. https://doi.org/10.1186/s12913-018-3116-8.

Asih (2018). Kesehatan dan Keselamatan Kerja Rumah Sakit. Jakarta Pusat: PT. TIM.

Dahal P (2017). Investing on occupational safety and health. Int J Occupational Safety and Health. 7(1): 1 - 1. https://doi.org/10.3126/ijosh.v7i1.22758.

Denzin NK, Lincoln YS (2018). Hand of book Qualitative Research Edisi I. Yogyakarta: Pustaka Pelajar.
Kim H, Jung MH (2015). Effect of occupational health nursing practice on musculoskeletal pains among hospital nursing staff in Korea. International Journal of Occupational Safety and Ergonomics. Int J Occup Saf Ergon. 22(2): 199-206. https://doi.org/10.1o8o/10803548.2015.1078046.

ILO-WHO (2005). Joint ILO/WHO Guidelines on Health Services and HIV/AIDS. Terj. Zulmiar Yanri et al., Pedoman Bersama ILO/WHO tentang Pelayanan Kesehatan dan HIV/AIDS. Jakarta: Depnakertrans RI. http://www.who.int/hiv/pub/guideli nes/who_ilo_guidelines_indonesian. pdf

Kementerian Kesehatan Republik Indonesia. 2010. Kepmenkes RI nomor $\quad$ 1087/menkes/VIII/2010. Standar Kesehatan dan Keselamatan Kerja di Rumah Sakit (K3RS). Jakarta.

Menteri Kesehatan Republik Indonesia. 2007. Keputusan Menteri Kesehatan Republik Indonesia Nomor 432/ MENKES/ SK/ IV/ 2007: Pedoman Manajemen Kesehatan dan Keselamatan Kerja (K3) di Rumah Sakit (Guidelines for Occupational Health and Safety (K3) Management in Hospitals). Jakarta.

Menteri Lingkungan Hidup dan Kehutanan Republik Indonesia (2015). Peraturan Menteri Lingkungan Hidup dan Kehutanan No. P.56. tentang tata cara dan persyaratan teknis pengelolaan limbah bahan berbahaya dan beracun dari fasilitas pelayanan kesehatan (Minister of Environment and Forestry Regulation page 56 about procedures and technical requirements for management of hazardous and toxic waste from health care facilities). Jakarta. 
Moleong (2012). Metode penelitian kualitatif (Qualitative research methods). Bandung: Remaja Rosda Karya

Murti B (2013). Desain dan ukuran sampel untuk penelitian kuantitatif dan kualitatif di bidang kesehatan (Design and sample size for quantitative and qualitative research in the health sector). Cetakan ke-3. Yogyakarta: Gajah Mada University Press.

Nasri(2002). Risiko tinggi di tempat kerja rumah sakit (High risk in hospital environment). In Aditama TY and Tri H. Kesehatan dan Keselamatan Kerja, Kumpulan Makalah Seminar K3 RS Persahabatan Tahun 2000-2001. Jakarta: UI Press.

National Institute for Occupational Safety and Health (2010). Slip, trip and fall prevention for healthcare workers. Atlanta. http://www.cdc.gov/niosh/docs/2011-123/pdfs/2011-123.pdf.

Ohnishi K (2015). Needle-stick dengue virus infection in a health-care worker at a Japanese hospital. J Occup Health. 57(5): 482-483. https://dx.doi.org/10.1539\%2Fjoh.14-0224-CS.

Park JH, Lee EN (2016). Nurses' safety in the hospital environment: Evolutionary concept analysis. J Korean Acad Nurs Adm. 22(4): 406-414. http://dx.doi.org/10.11111/jkana.2016.22.4.4 06.

Rezaei M, Golbabaei F, Behzadi MS (2017). Assessing the healthcare workers' knowledge, attitude, and practice toward health, safety, and environment in an educational hospital affiliated by Iran University of Medical Sciences (2012-2013). J Environment Sci Tech. 19(4): 347-355. https://dx.doi.org/10.22034/jest.2017.10736.
Mutifasari RS, Ramdhan DH, Bharata AY (2018). Occupational safety and health culture implementation in emergency department, operating room, and intensive care unit nurses at Hospital X" in International Conference of Occupational Health and Safety (ICOHS-2017), KnE Life Sciences. 599-606. DOI 10.18502/kls.v4i5.2589.

Riyanto A (2009). Pengolahan dan analisis data kesehatan (Health data processing and analysis). Yogyakarta: Jazamedia.

Mejia RR, González DJV, Duran AM (2021). Health-associated infection and Covid-19 in Mexico: safety and health rules at work or job biosecurity. Int J Occup Safety Health. 11(1): 54 - 64. https://doi.org/10.3126/ijosh.v11i1.34107.

Sasaki N, Asaoka H, Kuroda R, Tsuno K, Imamura K, Kawakami N (2021). Sustained poor mental health among healthcare workers in COVID-19 pandemic: A longitudinal analysis of the four-wave panel survey over 8 months in Japan. J Occup Health. 63:e12227. https://doi.org/10.1002/1348-9585.12227.

Soltanzadeh A, Heidari H, Hoseini Z, Sooroshnia M, Rahimifard H (2021). Safety risk assesment in medical and paramedical education laboratories. Arch Occup Health. 5(2): 971-979. doi: 10.18502/aoh.v5i2.6192.

Sugiyono (2013). Metode Penelitian Pendidikan Pendekatan Kuantitatif, Kualitatif. Bandung: Alfabeta.

WHO (2010). WHO guidelines on drawing blood: Best practices in phlebotomy. https://apps.who.int/iris/handle/106 65/44294. 